\title{
The New Wave of Service Integration
}

\author{
Jane Waldfogel \\ Columbia University
}

\begin{abstract}
States are pursuing service integration that differs substantively and strategically from the first wave of service integration in the 1970s. This article describes the new approach, using Maryland's Systems Reform Initiative as an example, and identifies the ways in which it differs from the original wave. The most important substantive difference is that, in contrast to the first wave, which emphasized administrative reforms, these new state initiatives include casework, governance, and financing reforms as well. There are also differences in strategy. The early wave favored top-down initiatives, combined with limited bottom-up activities such as pilot projects. The new wave, contrary to previous efforts, uses a "bootstrapping" approach, in which reform proceeds incrementally, local participants learn by doing, and the state learns by monitoring.
\end{abstract}

Service integration is undergoing a renaissance. State initiatives to improve the coordination and delivery of services for children and families are part of a new wave of service integration that has been seen across the country over the past 10 years. This movement shows no signs of abating. In fact, given the current trend toward block grants and devolution of authority for social services to states and localities, such initiatives may become even more widespread.

One aim of this article is to identify the ways in which the new wave of service integration differs from earlier efforts. These differences are both substantive and strategic: states are targeting casework, governance, and fiscal reforms in addition to the traditional administrative reforms, and states are using a new "bootstrapping" strategy. A second aim of this article is to inform future efforts by drawing lessons from the experiences of states currently undertaking reforms. This article 
follows one of the oldest and the most successful of the new state initiatives, Maryland's Systems Reform Initiative, from its inception in 1989 until 1994. The principal sources for this analysis are a 1992 case study and a 1994 sequel, ${ }^{1}$ various reports and documents produced by the state of Maryland, and phone and in-person interviews with state, county, and local officials, community members, workers, and clients conducted in 1994 and updated in 1997.

\section{A Brief History of Service Integration}

Service integration as an organizing principle for the delivery of services is only 25 years old, yet its philosophical origins can be traced to the settlement houses of the late nineteenth century. ${ }^{2}$ One can also identify some elements of service integration in the 1960s, in programs established in conjunction with the War on Poverty. ${ }^{3}$ Neighborhood multiservice centers, for example, offered a range of services in community-based settings. ${ }^{4}$ Even Head Start, a categorically funded program, can be thought of as an early example of service integration in that it offered child care along with complementary services such as health care and nutrition. It was not until 1971, however, that Elliot Richardson, then secretary of Health, Education, and Welfare (HEW), launched the first wave of coordinated efforts to integrate child and family services. The HEW services integration initiative aimed at "developing an integrated framework within which ongoing programs can be rationalized and enriched to do a better job of making services available within the existing commitments and resources." ${ }^{\text {Richard- }}$ son's goal was to reform what he called the "bureaucratic labyrinth." At the federal level, there were more than 300 separate programs administered by HEW, and this proliferation of categorical programs extended to the state and local levels as well; a typical state had 100 separate departments administering the federal programs, and a typical city had some 500 different providers delivering the services. ${ }^{7}$ This fragmentation was particularly problematic because clients typically had multiple needs. By HEW's estimates, 85 percent of clients needed more than one service, yet, if referred to another provider for services, fewer than 20 percent would actually receive them. ${ }^{8}$

To encourage states to reduce fragmentation and move toward greater integration of services, Richardson sponsored "top-down" and "bottom-up" reform. ${ }^{9}$ Top-down reform from HEW's perspective consisted mainly of awarding planning grants. As implemented by the states, top-down reform most often consisted of executive office or agency reorganizations or planning initiatives; in fact, 29 states reorganized their state agencies as part of service integration initiatives in the 1970s or early 1980s. HEW's bottom-up reforms, which included Services Integration Targets of Opportunity (SITO) grants, gave states 
and localities more autonomy and flexibility in using federal funds on the condition that they implemented reforms aimed at integrating services. Typically, these reforms occurred in selected local areas or programs on a pilot basis.

The first wave of service integration was extensively studied. There were literally hundreds of studies of the state and local projects that were sponsored under the HEW service integration initiative. There were also several evaluations of the initiative as a whole, including an official HEW evaluation in $1972 .{ }^{10}$ The HEW evaluators looked at the extent to which localities had met the goal of "the linking together by various means of the services of two or more service providers to allow treatment of an individual's or family's needs in a more coordinated and comprehensive manner." "From studies of 30 local sites (and four states), the evaluators concluded that many of the ostensibly participating communities had taken no, or only limited, concrete steps to implement this goal. ${ }^{12}$ As a result, they concluded, integration of services was "not extensive." 13 Other evaluators criticized the lack of outcome data. ${ }^{14}$ The overall consensus from these studies was that, although promising in theory, the first wave of reforms was disappointing in practice. Nor were other, related initiatives any more successful. Title XX, the Social Services Block Grant of 1975, which decategorized funding for a variety of social services programs, was in theory another step in the direction of service integration. ${ }^{15}$ In practice, however, the block grant had little effect because no new funds were allocated, and it proved difficult to take funds away from existing programs. ${ }^{16}$

The extremely limited successes, and in some cases outright failures, of these early efforts did little, however, to tarnish the concept of service integration. Janet Weiss has argued in an influential essay that this was due to the potency of service integration as a symbol. ${ }^{17}$ Pulling services together into a comprehensive package is such a patently sensible concept that it is difficult to reject, even in the face of evidence to the contrary. Further, the evidence is not clear-cut because service integration was never really given a chance in those early, halfhearted efforts. Goals were often vaguely stated, and implementation was haphazard at best. ${ }^{18}$ Another limitation was that the first wave emphasized administrative reforms, such as reorganizing state agencies or building links between local program administrators, instead of casework reforms. ${ }^{19}$ This is an important shortcoming. We would expect a priori that changes in casework practice should have a larger effect on streetlevel interactions between workers and clients than administrative reforms, which might have, at best, an indirect effect on innovations in service delivery. ${ }^{20}$

Given the spotty history of the first wave, it is not surprising that the current wave of service integration initiatives rarely invokes its 
historical antecedents. Rather, service integration is commonly presented as a new approach to the ever more complex needs of multiproblem families and to the ever-tightening constraints of limited federal, state, and local budgets. In its new incarnation, service integration has taken hold very quickly. Beginning with a renaissance in the midto late-1980s, service integration is now at the forefront of reform efforts across the whole range of human services. ${ }^{21}$ In education, reform efforts have centered on school-based or school-linked programs such as comprehensive youth service clinics. ${ }^{22}$ In child welfare, service integration initiatives have included decategorizing funding sources for child and family services, introducing family preservation models, and developing family support centers. ${ }^{23}$ In public welfare, in part spurred by the Family Support Act of 1988 but also by the search for administrative cost savings, virtually all the states have made some effort to introduce case management for welfare clients and to harmonize intake procedures across public assistance programs. ${ }^{24}$

Some of the current service integration efforts look a great deal like the first wave of reform. A popular mechanism for reform, as in the first wave of service integration, is restructuring across agency boundaries. Colorado, for example, after extensive research and planning, recently reorganized its state agency structure, combining three departments into a new Department of Human Services. ${ }^{25}$ This was not the sole focus of Colorado's initiative, but it was the major one. ${ }^{26}$ Yet, as in the first wave of reform, a fundamental question remains: how much effect should we expect any administrative restructuring to have on street-level service delivery as experienced by individual children and families?

Maryland is not alone in undertaking service integration efforts. In addition to the states mentioned above, several others have experimented with service integration in recent years, and efforts are underway in Arkansas, California, Florida, Georgia, Missouri, Oregon, and Vermont. ${ }^{27}$ Maryland is unique, however, in several respects. First, Maryland has been pursuing a service integration agenda since 1989. Thus, Maryland was one of the initiators in this wave of service integration and offers the opportunity to study a state that is relatively far along in reform. Maryland is also unique in the scope of its initiative. Under the rubric of its Systems Reform Initiative, Maryland has aimed for statewide reforms across a range of service delivery systems, unlike other states, which have supported pilot projects only or have tackled only one or two service delivery systems. Maryland has also made the most progress in reforms other than the typical agency reorganizations; it has pursued casework reforms as well as reforms in governance and financing. Further, Maryland is unique in its strategic approach to reform. It provides the best example of a state using a "bootstrapping" strategy of state-supported, locally coordinated re- 
form, in contrast with the more traditional top-down strategy seen in states such as Colorado.

\section{What Are the Goals of the New Wave of Service Integration?}

Service integration (or services integration, as it is sometimes called) has been defined by Alfred Kahn and Sheila Kamerman as "a systematic effort to solve problems of service fragmentation and of the lack of an exact match between an individual or family with problems and needs and an interventive program or professional specialty," with the goal of creating a "coherent and responsive human services system."28 Thus, the problem to be remedied is not so much an overall lack of resources as it is a problem of fragmented, misallocated, and mismatched resources.

The basic premise of service integration is that individuals and families who have complex and multiple needs are not well served by a service delivery system that is specialized and categorical. Although scholars differ on the rationale for service integration, many would agree that the principal problems service integration initiatives seek to address are availability and efficiency. ${ }^{29}$ The availability problem concerns both access and coordination. Clients find that no one agency is concerned with the full range of their problems; professionals frequently do not attend to problems outside of their area of expertise and often offer little or no guidance in where a client might turn for help. ${ }^{30}$ Clients must act as their own case managers, piecing together a package of services that meet their multiple needs.

Whether this is an undesirable model from the perspective of individuals and families is not immediately apparent. On the one hand, it allows clients, at least in principle, the choice of services and providers. It also affords clients a measure of privacy, as one provider need not know about the other services a client is receiving. The disadvantages, though, are likely greater. Shopping around for services places a heavy burden on already troubled individuals and families, and clients vary in their ability and willingness to use services. ${ }^{31}$ Those who need services the most might be least capable of being their own case manager and thus might fall through the cracks. Even clients who are well positioned to negotiate the system often trip up along the way due to conflicting eligibility requirements, lack of information, difficulties with transportation and child care, and so forth.

The other impetus for reform, efficiency, stems from the concern that the mismatch between client needs and agency services may result in less effective service delivery and less efficient use of resources. In the face of a mismatch, an agency may offer a second-best solution, that is, an alternative service that is not exactly what the client needs 
but that is the best that the agency currently has available. If a mother who needs substance abuse treatment is offered a parenting group instead, the problem is not just that the client's addiction, which endangers her child, is going untreated. The problem is also that the agency is essentially wasting its resources. A natural solution would be for the agency either to offer substance abuse treatment itself or to ensure that its clients can get such treatment elsewhere. The waste problem becomes even more pressing when the second-best service (e.g., residential treatment) costs more than the preferred but unavailable alternative (community-based day treatment). This was an important impetus for reform in Maryland.

The goals of service integration efforts are, first, to attain a better match between clients' needs and the services provided and, second, to create a more coordinated system for delivering those services. Attaining these goals requires both the capacity to identify individuals' and families' needs and the capacity to make adjustments to the service delivery system to meet those needs. At the state level, this means having a process to identify and adapt to changing needs. It also means removing barriers to integration and taking positive steps to facilitate integration, whether through integrating services in existing programs or coordinating services across programs.

This process of needs assessment and planning need not occur at the state level. It could be done by a county or even a locality on behalf of the state. In fact, I would argue that some level of delegation to local actors must be used if the state is to improve the match between needs and the service delivery system. No matter how well informed the state, the locality is likely to be better positioned to identify its residents' needs. This means that, if states are to achieve a more exact match, they must allow much more flexibility in both planning and funding at the local level. In the same way, agencies that aim to improve the match between their services and their clients' needs must allow more discretion by individual workers, who are best positioned to ascertain individuals' and families' needs and to identify an array of services to meet those needs. ${ }^{32}$

\section{Three Dimensions of Service Integration}

As shown in table 1, service integration includes a broad range of activities. ${ }^{33}$ These can be usefully characterized along three dimensions: the type, level, and locus of reform. ${ }^{34}$

The first dimension along which service integration efforts can vary is the type of reform. Scholarship on service integration traditionally makes a distinction between two types of activities: administrative and casework. ${ }^{35}$ Within the category of administrative reforms, however, one can further distinguish between traditional administrative reforms 


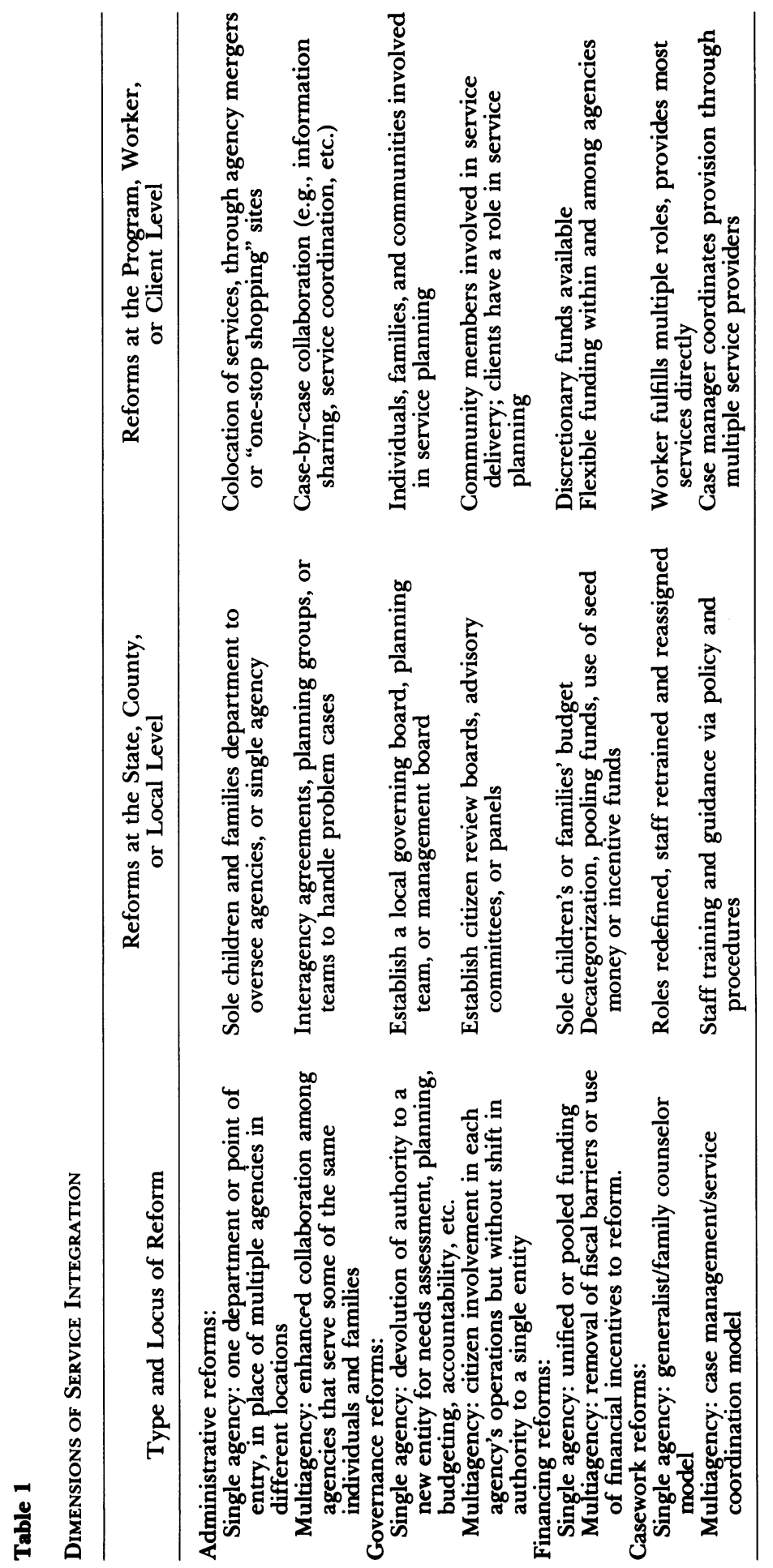


(such as agency reorganizations) and more innovative governance and fiscal reforms. These distinctions are important, particularly when comparing the current wave of reform with the earlier one. As noted above, the first wave of service integration initiatives focused almost exclusively on administrative changes in the form of agency reorganizations. The current wave of reform efforts also places much emphasis on administrative reforms but may include governance and financing as well as agency restructuring. The current wave is also more likely to feature casework reforms.

A second dimension of service integration is the level at which the reform is undertaken. As indicated in the table, reform can occur at the level of government (whether state, county, or local) or at the street level, with administrative reforms most often occurring at the level of government and casework reforms at the street level. This dimension is also important in comparing the current wave of reforms, which tend to focus more on the street level, with the reforms of the past, which more often emphasized changes within government whether at the state, county, or local level.

A third dimension is the locus of reform, which may be a single agency or multiple agencies. Single-agency reforms focus on integrating services within agencies by, for example, merging departments, breaking down professional boundaries, creating a joint planning process, and unifying funding streams. Multiagency reforms aim to integrate between agencies by, for example, building collaboration across departments, using case management models and teams to coordinate service delivery, and using funding mechanisms to promote better matches between clients and services. This distinction is also useful in comparing current and past waves of reform. The early wave emphasized multiagency initiatives; the current wave focuses more attention on improving coordination within agencies.

\section{Barriers to Reform and Strategies for Reform}

Current service integration initiatives frequently encounter barriers to reform, as the first wave of reforms did in the past. ${ }^{36}$ An important barrier is fiscal and caseload pressure; although this pressure can provide some of the impetus for reform, it also constrains reform. Also, as in the first wave, rhetoric by government leaders and policy makers about sweeping changes often exceeds the ability or willingness of localities to implement the changes. This is particularly problematic in states that use a top-down strategy. Political changes and uncertainty can cloud the vision and slow momentum. Another barrier is bureaucratic inertia ("if we drag our heels, we can just wait for this new initiative to pass"). A final barrier is risk aversion, particularly in agen- 
cies that deal with high-risk and highly visible populations (such as abused and neglected children) where the political costs of making a wrong move are very high.

The above barriers are not unique to service integration reforms; they are obstacles to any attempts at statewide reforms. However, there are additional barriers that make service integration more difficult than other state-led reforms. One problem is that there are specific features of the existing child and family services system that make transition to a more integrated system difficult. ${ }^{37}$ These features include categorical funding that encourages agencies to draw a sharp line between those they will serve and those they will not; the orientation and training of professionals that lead them to believe that clients are best served by individual specialists rather than generalists; and "turfism," historical rivalries, and mistrust among agencies that now must collaborate.

Another extremely important barrier is uncertainty. Despite the strong conceptual appeal of service integration, no one at the state level is entirely sure how the new models of casework, administrative structure, governance, and financing will work in practice or of how to get from here to there. How best to manage this uncertainty is a difficult question. A state that maintains that it has all the answers is bound to meet local resistance, while a state that encourages local input, as Maryland does, gains in terms of learning as it goes along but risks diminishing its credibility and authority. Although there are risks associated with being too rigid or too flexible about how an initiative should proceed, there nevertheless are advantages to being open to the possibility of change as an initiative moves forward. Robert Behn has called this process "management by groping along." ${ }^{8}$ State managers should be clear and firm about their overall agenda but should allow for flexibility in how that agenda will be achieved. This kind of "tight-loose" approach has (at least) two benefits. First, it permits and encourages frontline participants to share their insights and ideas for improving the initiative. Second, it gives planners the opportunity to learn from local practitioners and to change strategy as needed. Another reason for allowing local feedback is that it will improve the chances for successful implementation. ${ }^{39}$

Political scientists refer to the process of making corrections as one gains experience as "learning by doing." In a very interesting recent elaboration, Charles Sabel extends this analysis to what he calls "learning by monitoring." 40 Learning by monitoring is the process by which individuals not directly involved in implementation (such as planners, managers, or coordinators) make corrections based on their observation of and interactions with local actors who have firsthand experience with the innovation. Learning by monitoring is characteristic of organi- 
zational entities that are supporting flexible, systemic reform when the goals are clear but the pathway to attain those goals is not. Sabel calls this type of reform "bootstrapping." 41

Although Sabel primarily describes bootstrapping reform in privatesector industrial settings seeking to introduce more flexible and teamoriented production methods, the parallels with service integration initiatives in the public services sector are striking. Sabel argues that providing flexibility and autonomy to local actors, including the opportunity for them to influence the direction of the reforms through continuous monitoring and feedback, is beneficial not just because it is consistent with the nature of reform but also because it allows for learning by doing and learning by monitoring. This dual imperative applies to service integration as well. As noted earlier, if local service planners and caseworkers are to provide more integrated, flexible, and coordinated services, then they must be given more flexibility and autonomy. This will provide the opportunity for these local actors to learn by doing and to communicate their new knowledge to the statewide planners, who will learn by monitoring and amend their plans accordingly.

This bootstrapping strategy, where the state provides clear direction but also allows and learns from local flexibility, is evident in Maryland's Systems Reform Initiative, described below. This case also illustrates the multiple dimensions present in the current wave of service integration as well as the barriers to reform.

\section{Maryland's Systems Reform Initiative}

Maryland's approach to integrating child and family services, which it calls "systems reform," is an incremental one. This incrementalism makes it easy for observers, and even participants, to underestimate the scope of what Maryland has been aiming to achieve. Another reason it is difficult to grasp the scope of the agenda is that Maryland has attempted reforms across a whole range of social services (e.g., family preservation, family support centers, and welfare reform). At first glance, this proliferation of reform programs can obscure the overall systems reform agenda. On closer examination, however, both the breadth of its agenda and its incremental approach to systems reform make Maryland a particularly interesting case.

Maryland has been pioneering selected service integration models such as family centers and family preservation programs since the mid1980s, with important support from the Annie E. Casey Foundation. However, its official service integration initiative dates from 1989. In May of that year, Governor William Donald Schaefer appointed Nancy Grasmick as his special secretary for children, youth, and families (she later became superintendent of education as well). He also established 
a subcabinet for children and youth, made up of the commissioners of the agencies with responsibility for children and youth, and named Grasmick as its chair. In December 1989, Maryland was one of 10 states selected to participate in a State Policy Academy on Families and Children at Risk sponsored by the Council of Governors' Policy Advisors. ${ }^{42}$ Shortly thereafter, Maryland was one of three Policy Academy states chosen to receive Ford Foundation funding for its initiative. $^{43}$

Early in 1990, Grasmick hired a full-time director, Donna Stark, for Maryland's Children and Family Services Reform Initiative, later rechristened the Systems Reform Initiative (SRI). The initiative has three specific goals: to move authority for planning and purchasing services to the local community level (governance reform), to change the funding for services from categorical to pooled and from restricted to flexible (fiscal reform), and to reform service delivery to better reflect the principles of family preservation and family support, in particular, treating the family as a unit, viewing families as partners, and building on families' strengths (casework reform). It is striking that traditional administrative reforms such as agency reorganizations were not a prominent part of Maryland's agenda. Grasmick pursued administrative reform only as necessary to permit and support systemic change. For example, she fought for several years to establish a new unified department for families and children before eventually abandoning it as politically unfeasible.

Maryland approached service integration with a bootstrapping strategy designed to combine strong state leadership with significant local authority. To ensure that the localities were ready to assume this authority, Grasmick and Stark decided to introduce systems reform incrementally. Thus, although SRI would ultimately involve statewide and systemwide reforms, they started with only one county and a few services and then added more counties and services over time. The choice of the first county was an important one. Maryland was fortunate to have in Prince George's County a local community that already had experience both with the concept of service integration and with the philosophy of family preservation through its participation in the Annie E. Casey Foundation Child Welfare Reform Initiative. Starting with a county that was primed for success helped when the time came to expand to other counties, and by early 1994, Maryland was more than halfway there, with systems reform under way in 12 of its 24 counties. ${ }^{44}$

Maryland chose two services to kick off systems reform: communitybased services to allow children to return from out-of-state placements, and family preservation services to prevent out-of-home placement. These choices fit in particularly well with Maryland's bootstrapping strategy of state-supported, locally coordinated reform. Bringing chil- 
dren back from expensive out-of-state placements was bound to be popular with legislators and state agency officials since these children were among the most costly in the system. As these children returned, the savings enabled Maryland, despite tight budgets, to create a pool of flexible incentive funds, which became available to support the local communities in their efforts to coordinate the purchase of new preventive services.

Family preservation services were also a good choice in launching the initiative. To the extent that system reform was about building local community capacity to plan and deliver services and to develop casework models with a family-focused philosophy, family preservation, with its emphasis on community and family partnerships, was the right service to help local areas move forward with governance and casework reforms.

The Systems Reform Initiative had mixed success in the legislature, and Maryland was unable to generate any substantial new funding for the initiative. Thus, political and fiscal pressures have hampered the reform effort. The initiative has also faced some of the barriers that typically impede service integration, although it is unclear that it has faced these head-on. For example, little attention has been paid to overcoming bureaucratic inertia by reaching staff within the state agencies and bringing them on board. Rather, the state's strategy appears to have been to bypass them by making changes at the top and at the level of the community. This is clearly a temporary solution, and in the next phase of reform, more attention will have to be paid to training staff within the state's child and family service agencies. A related barrier is resistance. At least one of the state agency heads is quite vocal about that agency's reluctance to participate in pooling funding, and it is unclear whether the initiative is dealing with that resistance.

Maryland did meet head-on the "uncertainty" barrier, that is, the realization that the state does not necessarily have all the right answers about what will make its initiative succeed. In this regard, Maryland exemplifies bootstrapping reform. Local actors, both the street-level practitioners and the local management boards, have been given permission to experiment, and the state has demonstrated its willingness to "learn by monitoring," that is, to amend its plans based on feedback from these local actors. Maryland has also shown flexibility in the elements that compose its strategic plan. For example, creating a single children's agency was high on Maryland's agenda for several years but has now been dropped.

The initiative's progress has been impressive. A 1992 report by the Council of Governors' Policy Advisors presented Maryland as the most advanced of the original 10 Policy Academy states, noting that "Maryland has made great strides in realizing this vision of a seamless system 
of services." ${ }^{45}$ Progress continued after 1992, as new counties and new services were brought on board. Five years into the initiative, in 1994, SRI was operating in half the state's counties, and several more were preparing to come on board. ${ }^{46}$ By the end of 1994, SRI was also reaching more parts of the service delivery system. Having begun with two specific populations (children in out-of-state placements and children at risk of placement), SRI was subsequently extended to other children and families as part of the process of "going to scale."

Going to scale extends systems reform on all four dimensions. On the administrative and casework dimensions, going to scale means including in the initiative the full range of child and family services, although there is still resistance within the system to including some services (e.g., services to delinquent youth). On the governance and fiscal dimensions, going to scale means giving local management boards more control over the selection and purchase of services. For counties that go to scale, this means that a local management board will be responsible for identifying which services to purchase with the state child and family services funds and from whom. The plan as of 1994 was that existing state agency service provision would be "grandfathered" for a period of several years, but after that, local management boards will be free to purchase services from whomever they think best (i.e., a local area might continue to buy child protective services investigations from the state child protective agency or might switch to a community agency, depending on local needs and local capacity). ${ }^{47}$

\section{Evaluating the Success of Maryland's Initiative}

To evaluate the success of a reform initiative in accomplishing service integration, it is important to determine not only whether specific goals were achieved but also whether outcomes can, with some fairly high degree of certainty, be attributed to the initiative. In Maryland, as is often the case, it is difficult to do this, but the results are suggestive.

An early, and important, component of Maryland's reform agenda was to return children from unnecessary and expensive out-of-state placements to alternative programs in the community; it also aimed to prevent such placements in the future. On the face of it, evaluating success on this component is straightforward. One can simply count the number of children returned from out-of-state placement, the number of children entering such placement, and the number of dollars saved. On each of these measures, Maryland has made progress, as documented in a 1994 status report. ${ }^{48}$ Between 1990 and 1993, the numbers of children returning from out-of-state placement increased by nearly one-third, from 205 to 271 . Over the same time period, the number of children entering out-of-state placements fell by 44 per- 
cent, from 310 to 174 . In 1993 alone, the increase in returns and reduction in entries freed up over $\$ 4$ million, which was given to the counties so that they could purchase new community-based services. These figures do not tell us conclusively that SRI caused the progress. Favorable demographic trends, falls in caseloads, and so forth, might have played a role. However, the figures are suggestive.

The difficulty in evaluating success becomes even more apparent when examining Maryland's other initial systems reform goal: preventing unnecessary out-of-home placements. The family counselors and families whom I interviewed in Maryland reported that the family preservation services offered under systems reform had played a key role in keeping families together. For example, an adolescent girl and her grandparents in Prince George's County said that, if not for the intervention of their family counselor, the girl would have been placed in foster care, as she had been in the past, due to the family's inability to negotiate issues such as curfews and after-school activities. This family also credited their family counselor with helping the girl stay in school because, when the school threatened to expel her due to her difficult behavior, the counselor accompanied the family to the school and helped arrange for the girl to continue attending school on a reduced schedule. The counselor also helped set up individual therapists for the girl and her grandmother. Once these supports were in place, the counselor closed the case, although he remained available to the family in case of emergency. According the family, however, they rarely had to contact him because he had helped them learn ways to cope with crises on their own. In another case, in Baltimore City, a mother with six children was referred to family preservation services because she was living in dangerous and inadequate housing. The children had been in foster care before, and the child welfare agency was contemplating placing them again. Instead, the family counselor helped the family find a new apartment and, using the family preservation agency's flexible funds, paid the costs for moving and for a refrigerator. Once the housing crisis was solved, the counselor and the mother worked together on other pressing issues, such helping the mother to arrange a test for the HIV virus and to set up therapy for her depression. The family counselor also used his own family connections to help the oldest child get a job after school. When I met the family and the counselor a year later, they were still in touch periodically, although the case was officially closed, and the mother credited the counselor with having saved her children from going back into foster care.

Reports such as these are encouraging, but, as the literature on the evaluation of family preservation programs attests, it is extremely difficult to establish the extent to which an intensive family intervention program actually prevents placements. ${ }^{49}$ Ideally, one would want 
a controlled experiment, in which comparable families were randomly assigned to either the treatment (in this case, family preservation) or the control (regular child welfare services) group, but Maryland did not undertake this type of experiment. Lacking an experimental framework, it is difficult to interpret the fact that only 16 percent of the children served in family preservation programs were placed into out-of-home care because we do not know what percentage would have been placed without the reform initiative.$^{50}$ One possible approach is to compare data on the numbers of children entering foster care in counties with family preservation programs versus those without such programs. This approach has some intuitive appeal because, if a family preservation program is working, the number of foster children in that area relative to other areas without such a program should decrease. Maryland provides data that allow for a comparison of Prince George's County, the flagship county, with the rest of the state from fiscal year 1989 to fiscal year 1993. Out-of-home placements by the child welfare agency, the Department of Human Resources (DHR), fell by 38 percent (from 523 in 1989 to 324 in 1993) in Prince George's County at a time when DHR out-of-home placement rates were essentially stable $(2,690$ and 2,696$)$ in the remainder of the state. Between 1991-93, placements by all state agencies fell by 19 percent in Prince George's County (from 837 to 676) while increasing 3 percent (from 5,309 to 5,466) in the remainder of the state. Eight other counties began participating 1 year after Prince George's County did, and it is clear from the data that these eight other participating counties have done less well. From 1991-93, while overall placements were decreasing 19 percent in Prince George's County, placements across the eight other participating counties increased 5 percent, comparable to (in fact, slightly worse than) the constant level of placements in the nonparticipating counties. Much of the increase was driven by the increase in the placement of delinquent youth in the largest participating county, Baltimore City, which offset the decrease in child welfare placements in that county and the others.

One might ask, however, whether the rest of the state is the right control group. Participation in systems reform, after all, was not on a random basis; rather, the counties that were best positioned and most willing participated first. The lower foster care numbers in Prince George's County, for example, might be due to characteristics of that county that have little to do with SRI. A second concern is controlling for other changes that occur in the counties over time. Changes unrelated to SRI, such as the increase in juvenile crime in Baltimore City in the early 1990s or the more recent increase in child abuse and neglect reports in Prince George's County, might affect the number of placements in some counties more than others. ${ }^{51}$ To control for some of this heterogeneity across counties, one ideally would use statis- 
tics on levels and changes in levels of child abuse and neglect referrals or delinquency referrals to estimate a county's foster care or juvenile detention placement rate as a percentage of all children at risk of placement (rather than simply counting the number of placements).

\section{Postscript: Systems Reform after 1994}

In the fall of 1994, Maryland elected a new governor, Parris Glendening, the former county executive from Prince George's County. Governor Glendening appointed a new special secretary for children, youth, and families in early 1995. Nancy Grasmick continued as the superintendent of education but no longer had responsibility for leading the systems reform effort. Although the new governor and secretary were supportive, systems reform foundered in that transition year. In early 1996, responding to concerns about the state of the initiative voiced by legislators, state administrators, and local participants, Governor Glendening established a systems reform task force, chaired by Lieutenant Governor Kathleen Kennedy Townsend. The task force's report, issued in November 1996, reaffirmed the commitment of the legislature, state executive, and counties to the principles of systems reform. ${ }^{52}$ The task force report also identified mechanisms for tracking results and accountability, and set out a strategy for moving the change effort forward. As a result, a new Systems Reform Commission with legislative, state, and county representation was established to direct the initiative. The commission's plans as of 1997 included bringing the nine remaining counties on board by the end of the year and supporting some of the original counties in taking the vision to scale. The task force also recommended strengthening the authority of the local management boards to set their own agendas for systems reform and to monitor outcomes for their counties.

Thus, although system reform stalled for a few years during the transition to a new administration, the effort is now back on track. The ability of SRI to weather the change seems to have occurred in large part because key participants from the executive, legislative, and local levels were familiar with and committed to the principles of systems reform. Although frustrated with the current status of systems reform, none of these key players is advocating turning back.

\section{Conclusion}

The reform initiative in Maryland is at the forefront of a new wave of service integration efforts being undertaken in states and localities across the country. The Maryland initiative sheds some light on the questions of whether this new wave of service integration reforms can be more successful than the earlier wave and, if so, how. There are 
three particularly striking findings that emerge from the analysis of this state's experience.

One lesson is that the distinction between administrative, casework, governance, and fiscal reforms matters. While state planners may perceive that agency reorganizations and other administrative reforms are equally, if not more, important, Maryland's experience seems to indicate that, in fact, casework, governance, and fiscal reforms are the critical ones. Maryland, after all, failed in its efforts at administrative reforms, but its initiative has nevertheless been markedly more successful than traditional reforms that focus on administrative restructuring. This suggests that the current wave of service integration initiatives, unlike the first wave of the 1970 s, is making more than a symbolic difference. As Mary Jo Bane has noted, the real measure of success of service integration reforms is whether they have made any difference in the lives of individual children and families by changing the service delivery within existing organizations or by creating new types of programs that better meet the needs of children and families. ${ }^{53} \mathrm{On}$ this measure, the reforms in Maryland have to be rated a qualified success. New programs that are more responsive to families' needs, such as family centers and family preservation services, have been established, and new operating procedures that allow workers more discretion, such as discretionary funds, have been implemented. The reforms, however limited, are real and are spreading. Although some resistance is evident, particularly within the traditional state agencies, it is also evident from the case study, reports, and interviews that there are many individuals and agencies who are committed to the principles of service integration and are actively espousing the reforms. There is substance, then, to this current wave, and this in large part appears to be due to the emphasis on casework, fiscal, and governance reforms rather than the traditional administrative ones.

A second lesson is that local program innovations can be extremely helpful in advancing a reform agenda, but that they also have limitations. Among local program innovations, family centers and family preservation programs have particular advantages. These program models deliver comprehensive family-focused services, benefiting families and demonstrating the value of service integration. Local policy teams are useful models as well. They involve local actors in a joint planning and service delivery process, breaking down barriers between agencies and helping to resolve old battles over turf and budgets. Another advantage of local policy teams is that they reinforce the notion that statewide planners may not have all the answers and that reform initiatives can benefit from learning by monitoring. The principal limitation of these local program innovations is that they may not necessarily affect operations within the existing service delivery system. It is not clear that the family support centers and family preservation 
programs in Maryland have had any effect on the state's child welfare agency. This is an important limitation because the majority of children and families continue to be served by the existing service delivery system.

Third, it now appears that, in order for service integration initiatives to make a difference at the street level, local actors will have to be given a greater degree of autonomy than has previously been envisioned. If services are to be truly responsive to the needs of individuals, families, and communities, these stakeholders must have input into decisions on what services are to be provided and how. Maryland learned this lesson, and citizen input is an important part of its reform agenda. This does not mean that there is no longer a role for state governments in service integration initiatives. On the contrary, state leadership is essential to facilitate and sponsor change, and states that wish to pursue service integration must continue to play a major role in initial planning, providing incentive funding and technical assistance, and drafting and sponsoring legislation, among other things. It does mean that states will be most effective in these efforts if they view themselves as acting in partnership with and learning from the localities, in a process of bootstrapping reform. It is interesting in this regard that in establishing its new commission to direct systems reform in 1997, Maryland moved the leadership of the initiative from a subcabinet group to a commission where 50 percent of the representation is from the local areas. At the same time, it moved to enhance the authority of the local management boards, which was one of the key recommendations of the 1996 task force. ${ }^{54}$

The Maryland Systems Reform Initiative provides some evidence that the new wave of service integration initiatives, unlike the earlier wave, can lead to changes that benefit children and families. The Maryland case provides some insights into how to get from here to there, but it also leaves intriguing questions unanswered. Further research is needed on bootstrapping reform and on the necessary conditions for state and local actors to work together to implement changes in governance and financing and to effect casework reforms within existing state agencies.

\section{Notes}

I am grateful to Mary Jo Bane, Linda Kaboolian, Mark Moore, Jack Needleman, Charles Sabel, and Teresa Eckrich Sommer for helpful comments and discussions. Funding for this project was provided by the Ford Foundation. The opinions expressed here are mine alone.

1. Kirsten Lundberg, "Integrating Family Services: Maryland" (Case C-16-91-1084.0 and Sequel C-16-91-1084.1, Harvard University, Kennedy School of Government Case Program, Cambridge, Mass., 1994).

2. For detailed histories of service integration, see Sharon Lynn Kagan, Integrating Human Services: Understanding the Past to Shape the Future (New Haven, Conn.: Yale 
University Press, 1994); Alfred Kahn and Sheila Kamerman, Integrating Services Integration: An Overview of Initiatives, Issues, and Possibilities (New York: Columbia University School of Public Health, National Center for Children in Poverty, 1992).

3. Robert Halpern, "Supportive Services for Families in Poverty: Dilemmas of Reform," Social Service Review 65, no. 3 (1991): 343-64.

4. Sheldon Gans and Gerald Horton, Integration of Human Services (New York: Praeger, 1975).

5. "Services Integration-Next Steps," Secretarial Memorandum, June 1, 1971, p. 1, cited in U.S. Department of Health, Education, and Welfare, Integration of Human Services in HEW: An Evaluation of Services Integration Projects, vol. 1 (Washington, D.C.: U.S. Department of Health, Education, and Welfare, 1976). The HEW initiative used the term "services integration," and this term was used throughout the 1970 s and even in some later literature. This has been replaced by "service integration" in the more recent literature. For this reason, I use "service integration" in this article except when referring specifically to the HEW initiative.

6. Elliot Richardson, Responsibility and Responsiveness: A Report on the HEW Potential for the Seventies (Washington, D.C.: U.S. Department of Health, Education, and Welfare, 1973), p. 42.

7. Ibid.

8. Ibid., p. 43.

9. Ibid., p. 55 .

10. The official HEW evaluation was initially released as U.S. Department of Health, Education, and Welfare, Integration of Human Services in HEW: An Evaluation of Services Integration Projects (Washington, D.C.: U.S. Department of Health, Education, and Welfare, 1972); see also Gans and Horton (n. 4 above). An earlier HEW evaluation was conducted in 1971; see Sidney Gardner, Services Integration in HEW: An Initial Report (Washington, D.C.: U.S. Department of Health, Education, and Welfare, 1971). Other evaluations include Abt Associates, Services Integration, Part II, Integrating Linkages (Cambridge, Mass.: Abt Associates, 1971); the Human Ecology Institute, Human Service Development Programs in Sixteen Allied Services (SITO) Projects (Wellesley, Mass.: Human Ecology Institute, 1975); and William Lucas, Aggregating Organizational Experience with Services Integration: Feasibility and Design (Santa Monica, Calif.: Rand, 1975). Robert Agranoff and Alex Pattakos, Dimensions of Services Integration: Service Delivery, Program Linkages, Policy Management, Organizational Structure (Washington, D.C.: Project SHARE, 1979), provide an overview of the SITO initiatives. Laurence Lynn, The State and Human Services: Organizational Change in a Political Context (Cambridge, Mass.: MIT Press, 1980), provides case studies and analysis of six state-level initiatives. Neil Gilbert and Harry Specht, Coordinating Social Services: An Analysis of Community, Organizational, and Staff Characteristics (New York: Praeger, 1977), provide an analysis of service integration in the Model Cities Program. For a listing of papers and publications about individual service integration projects undertaken in the 1970s, see Project SHARE, The Project Share Collection (Rockville, Md.: Project SHARE, 1979); see also Project SHARE, Services Integration Methodology (Rockville, Md.: Project SHARE, 1979).

11. U.S. Department of Health, Education, and Welfare, Integration of Human Services in $H E W, 1972$ (n. 10 above), p. 5.

12. Kagan (n. 2 above).

13. U.S. Department of Health, Education, and Welfare, Integration of Human Services in $H E W, 1972$ (n. 10 above), p. 16.

14. Lucas (n. 10 above).

15. Kahn and Kamerman (n. 2 above).

16. Mary Jo Bane and Susan Lusi, "The Federal Role in Improving Services" (Working Paper no. ES-91-2, Harvard University, Kennedy School of Government, Malcolm Wiener Center for Social Policy, 1991).

17. Janet Weiss, "Substance versus Symbol in Administrative Reform," Policy Analysis (Winter 1981): 20-45.

18. Gans and Horton (n. 4 above).

$\rightarrow$ Robert Agranoff, "Human Services Integration: Past and Present Challenges in Public Administration," Public Administration Review 51, no. 6 (1991): 533-42; David Austin, "Administrative Issues in Improving the Provision of Human Services," in Human Services Coordination, ed. Harold Orlans (New York: Pica, 1982). 
20. Charles Bruner, "Is Change from Above Possible? State-Level Strategies for Supporting Street-Level Services" (Working Paper no. ES-91-6, Harvard University, Kennedy School of Government, Malcolm Wiener Center for Social Policy, 1991); Mary Jo Bane, "Integrating Family Services: The State Role" (report to the Ford Foundation, Harvard University, Kennedy School of Government, Malcolm Wiener Center for Social Policy, 1992).

21. Kahn and Kamerman (n. 2 above).

22. Gerry Martin, A Joint Enterprise with America's Families to Assure School Success (Washington, D.C.: Council of State School Officers, 1993). California and New Jersey are particularly prominent examples. See, e.g., Kagan (n. 2 above); Larry Best, "Institutions Which Promote Social Services Integration: An Analysis of Top-Down vs. BottomUp Approaches" (paper presented at the Association for Public Policy Analysis and Management, Washington, D.C., 1995).

23. Charles Bruner and D. Flintrop, Developing Comprehensive Family Centered Child Welfare Systems: Emerging State Strategies (Des Moines, Iowa: Child and Family Policy Center, 1991); Jill Kinney, David Haapala, and Charlotte Booth, Keeping Families Together: The Homebuilders Model (Hawthorne: Aldine de Gruyter, 1991); Carol Dunst, Carol Trivette, and Angela Deal, eds., Supporting and Strengthening Families (Cambridge, Mass.: Brookline Books, 1994).

24. Olivia Golden, Poor Children and Welfare Reform (Westport, Conn.: Greenwood, 1992); Allen Kraus and Jolie Bain Pillsbury, "Streamlining Intake and Eligibility Systems: A Review of the Practice and the Possible" (New York: Center for Assessment and Policy Development, 1993). Service integration is also an important element of welfare reform initiatives in states such as Michigan and Iowa that have adopted a case management approach to moving recipients from welfare to work.

25. Kirsten Lundberg, "Integrating Family Services: Colorado" (Case C-16-91-1082.0 and Sequel C-16-91-1082.1, Harvard University, Kennedy School of Government Case Program, Cambridge, Mass., 1994); Jane Waldfogel, "Integrating Child and Family Services: Lessons from Arkansas, Colorado, and Maryland" (report to the Ford Foundation, Harvard University, Kennedy School of Government, Malcolm Wiener Center for Social Policy, 1994).

26. Lundberg (n. 25 above); Waldfogel (n. 25 above).

27. Jane Knitzer and Stephen Page, Mapping and Tracking State Initiatives to Meet the Needs of Young Children and Families (New York: National Center for Children in Poverty, 1996).

28. Kahn and Kamerman (n. 2 above), p. 5.

29. Kagan (n. 2 above); Gans and Horton (n. 4 above).

30. Lisbeth Schorr, Within Our Reach: Breaking the Cycle of Disadvantage (New York: Doubleday, 1989).

31. Teresa Eckrich Sommer, "Low-Income Families as Customers of the Social Service System: Implications for Practice and System Reform" (Ph.D. diss., Kennedy School of Government, Harvard University, 1995).

32. See, e.g., Schorr, Within Our Reach (n. 30 above).

33. For a comprehensive listing of service integration activities, see Olivia Golden "Collaboration as a Means, Not an End," in Lisbeth Schorr, ed., Effective Services for Young Children (Ann Arbor, Mich.: Books on Demand, 1991); Kagan (n. 2 above); Kahn and Kamerman (n. 2 above).

34. I am using dimension in a different sense than Agranoff and Pattakos (see n. 10 above). Their four dimensions (service delivery, program linkages, policy management, and organizational structure) refer to components of service integration efforts, whereas the three dimensions used here (type, level, and locus of reform) refer to characteristics.

35. Agranoff (n. 19 above); Gans and Horton (n. 4 above); Kagan (n. 2 above); Kahn and Kamerman (n. 2 abor $\rightarrow$ F. Stevens Redburn, "On Human Services Integration," Public Administration Review 37 (1977): 264-69.

36. Orlans, ed. (n. 19 above); Kagan (n. 2 above).

37. $\rightarrow$ Frank Farrow and Tom Joe, "Financing School-Linked, Integrated Services," Future of Children 2, no. 1 (1992): 56-67. Kagan (n. 2 above).

$\vdots \rightarrow$ Robert Behn, "Management by Groping Along," Journal of Policy Analysis and Management 7, no. 4 (1988): 643-63, and Leadership Counts: Lessons for Public Managers 
from the Massachusetts Welfare, Training, and Employment Program (Cambridge, Mass.: Harvard University Press, $19 \subseteq \rightarrow$ Olivia Golden, "Innovation in Public Sector Human Services Programs: The Implications of Innovation by 'Groping Along,' Journal of Policy Analysis and Management 9, no. 2 (1990): 219-48.

39. See Richard Elmore, "Backward Mapping: Implementation Research and Policy Decisions," Political Science Quarterly 94, no. 4 (Winter 1979-80): 601-18.

40. Charles Sabel, "Learning by Monitoring," in The Handbook of Economic Sociology, ed. Neil Smelser and Richard Swedberg (Princeton, N.J.: Princeton University Press, 1994). On the related concept of "learning organizations," see Sid Gardner, "Afterword," in The Politics of Linking Schools and Social Services, ed. Louise Adler and Sid Gardner (Washington, D.C.: Falmer, 1994).

41. Charles Sabel, "Bootstrapping Reform: Rebuilding Firms, the Welfare State, and Unions" (Cambridge: Massachusetts Institute of Technology, 1994).

42. Ten states (Arkansas, Colorado, Illinois, Iowa, Maryland, New York, North Dakota, Oregon, Texas, and Washington) participated in this academy, which focused on supporting state efforts to integrate child and family services. Seven additional states (Arizona, Georgia, Hawaii, Indiana, Nevada, Ohio, and Oklahoma) participated in a second academy held in 1991 and 1992. The progress of the states participating in the first academy is documented in Judith Chynoweth, Lauren Cook, Michael Campbell, and Barbara Dyer, Experiments in Systems Change: Stated Implement Family Policy (Washington, D.C.: Council of Governors' Policy Advisors, 1992). For a report on the second academy, see Kathryn Nelson, Susan Foster, and Joseph Cocozza, Voices from the Field: Lessons from the Family Academy (Washington, D.C.: Council of Governors' Policy Academy, 1994).

43. The other two states were Arkansas and Colorado. For a comparative study of the three states, see Waldfogel (n. 25 above).

44. Three more counties formally joined the initiative between 1994 and 1996 . The other nine counties were due to come on board by the end of 1997. See State of Maryland Subcabinet for Children, Youth, and Families, "Systems Reform Status of Local Management Boards as of January 1997" (Baltimore: State of Maryland Subcabinet for Children, Youth, and Families, 1997).

45. The report found that three other states (Colorado, Texas, and Washington) had made significant changes; five (Arkansas, Oregon, Iowa, New York, and North Dakota) had made little or no progress; and one (Illinois) had abandoned the initiative. See Chynoweth et al. (n. 42 above).

46. As of January 1997, systems reform was fully operational in all but nine counties. Six of these had already established local management boards, and all nine were to begin implementation in July. See State of Maryland Subcabinet for Children, Youth, and Families, "Systems Reform Status of Local Management Boards" (n. 44 above), and "Subcabinet for Children, Youth, and Families and Systems Reform Initiative: Initiatives and FY 1996 Accomplishments" (Baltimore: State of Maryland Subcabinet for Children, Youth, and Families, 1997).

47. As of 1997, no counties had yet gone to scale, but the state and counties were continuing to move in that direction, with three counties identified as "vision to scale" pilot areas. The new Systems Reform Commission has a "vision to scale" subcommittee that will work with the counties that want to go to scale. See Governor's Task Force on Children, Youth, and Families Systems Reform, Final Report of the Governor's Task Force on Children, Youth, and Families Systems Reform (Baltimore: Governor's Task Force on Children, Youth, and Families Systems Reform, 1996).

48. State of Maryland Subcabinet for Children, Youth and Families, Status of Systems Reform: Fiscal Year 1993 (Baltimore: State of Maryland Subcabinet for Children, Youth and Families, 1994). Unless otherwise noted, all statistics from this report refer to fiscal year data.

49. John Schuerman, Tina Rzepnicki, and Julia Littell, Putting Families First: An Experiment in Family Preservation (Hawthorne, N.Y.: Aldine de Gruyter, 1994); Peter Rossi, "Assessing Family Preservation Programs," Children and Youth Services Review 14, no. 2 (1992: 77-97, "Strategies for Evaluation," Children and Youth Services Review 14, no. 2 (1992): $167-91$.

50. State of Maryland Subcabinet for Children, Youth and Families, "Systems Reform Status of Local Management Boards" (n. 44 above). 
51. Ibid.; State of Maryland Department of Human Resources, Monthly Management Report: April 1994 (Baltimore: State of Maryland Department of Human Resources, 1994).

52. See Governor's Task Force on Children, Youth, and Families Systems Reform (n. 47 above).

53. Bane (n. 20 above).

54. See Governor's Task Force on Children, Youth, and Families Systems Reform (n. 47 above). 